\title{
A COMPARISON OF THE DIRECT FICK AND THE GROLLMAN METHODS FOR DETERMINATION OF THE CARDIAC OUTPUT IN MAN
}

\author{
BY LARS WERKÖ, STIG BERSEUS, AND HENRIK LAGERLÖF \\ (From the IVth Medical Service, St. Eriks Hospital, and the Medical Department, \\ the Serafimer Hospital, Stockholm, Sweden)
}

(Received for publication September 14, 1948)

The introduction of the cardiac catheter by Forssman (1) and its later development as a useful physiological instrument by Cournand $(2,3)$ have made possible the determination of the cardiac output by the direct Fick principle in man (4). Using this method, a number of investigators have reported values of 5.5 to 6.5 liters per minute for the basal cardiac output, which correspond to 3.1 to 3.8 liters per minute per square meter of body surface area $(3,5-8)$. These values are higher than those obtained earlier with the Grollman acetylene inhalation method or the Krogh-Lindhard nitrogen oxide method (3.9 liters per minute) (9-12). The arteriovenous oxygen difference, determined according to the Fick method, has been found to be 40 to $45 \mathrm{cc}$. per liter of blood, as compared with $60 \mathrm{cc}$. per liter of blood using the acetylene method. This discrepancy has been discussed at length. It has been suggested by those working with the gas inhalation methods, that the heart catheterization procedure so disturbs the subject, that basal values cannot be secured. Different investigators using the catheter technique have obtained the same values in similar series, without an increase in oxygen consumption, heart rate or blood pressure (3), and have pointed out that these values have all varied consistently from those obtained by the Grollman technique.

The purpose of the work described in this study was to determine the cardiac output simultaneously by both methods and to account for any differences noted.

\section{MATERIAL AND METHOD}

Medical students, nurses or patients with minor cardiovascular diseases were used as subjects.

The subjects were trained for the Grollman technique the day before the study. The heart catheterization was done according to earlier descriptions $(3,8)$. The sample of mixed venous blood was always taken from the pulmonary artery and the arterial blood from the brachial artery. The first cardiac output was determined according to the Fick principle after the heart catheter and the arterial needle had been in place for at least 30 minutes.

Immediately after the first Fick determination, the acetylene rebreathing was performed. The first sample of alveolar air was taken 17 to 18 seconds and the second 26 to 27 seconds after the start of rebreathing acetylene $(10,11,13,14)$. Twenty to 30 minutes later the same procedure was repeated. Twenty to 30 minutes later a third Grollman determination was done.

Twenty minutes later a single blood sample was drawn from the pulmonary artery. Immediately afterward a rebreathing according to Grollman but without acetylene was performed. Another blood sample from the pulmonary artery was drawn between 17 and 27 seconds after the start of rebreathing. These samples were analyzed for oxygen content on the Van Slyke apparatus in order to establish the influence of the rebreathing procedure on the mixed venous blood and the arteriovenous oxygen difference.

In three subjects the effect of recirculation was studied. Blood was drawn in five second periods from the pulmonary artery, during the rebreathing of acetylene. The blood was analyzed for acetylene content of the Van Slyke volumetric apparatus. In each subject two to three experiments were done. It was usually possible to obtain blood during two five second periods at each experiment, for example, between five to 10 and between 15 to 20 seconds after the start of acetylene breathing.

\section{RESULTS}

In Table I the age of the subject, diagnosis, oxygen consumption, and the arteriovenous oxygen difference obtained with the two methods are tabulated. The values for arteriovenous oxygen difference using the acetylene method were always larger than those obtained according to the direct Fick method. The difference varied between 5 and $49 \mathrm{cc}$. per liter with a mean of $26.5 \pm 2.79$ and was not proportional to the value given by the Fick method. The third determination of arteriovenous oxygen difference in each subject was done after allowing a 20 minute interval between the two methods. If these are excluded, the dif- 
TABLE I

\begin{tabular}{|c|c|c|c|c|c|c|}
\hline \multirow{2}{*}{$\begin{array}{c}\text { Patient } \\
\text { Age } \\
\text { Sex }\end{array}$} & \multirow[b]{2}{*}{ Diagnosis } & \multirow[b]{2}{*}{$\mathrm{O}_{2}$-consumption } & \multirow[b]{2}{*}{ B.M.R. } & \multicolumn{3}{|c|}{ Arteriovenous $\mathrm{O}_{2}$-difference } \\
\hline & & & & $\begin{array}{l}\text { Catheter } \\
\text { method }\end{array}$ & $\underset{\text { method }}{\text { Grollman }}$ & $\begin{array}{l}\text { Difference } \\
\text { Grollman- } \\
\text { Catheter }\end{array}$ \\
\hline 52 years & Ess. hypertension & $\begin{array}{c}c c . / m i n \\
277 \\
277\end{array}$ & $\begin{array}{l}\text { per cent } \\
+27 \\
+27\end{array}$ & $\begin{array}{c}\text { cc./liter } \\
37 \\
36\end{array}$ & $\begin{array}{c}\text { cc. /liter } \\
50 \\
74\end{array}$ & $\begin{array}{l}13 \\
38\end{array}$ \\
\hline $24 \begin{array}{l}2 . \\
\text { years }\end{array}$ & Normal & $\begin{array}{l}234 \\
250\end{array}$ & $\begin{array}{l}-10 \\
--4\end{array}$ & $\begin{array}{l}36 \\
38 \\
39\end{array}$ & $\begin{array}{l}52 \\
61 \\
75\end{array}$ & $\begin{array}{l}16 \\
23 \\
36\end{array}$ \\
\hline 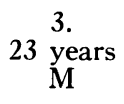 & Normal & $\begin{array}{l}235 \\
277\end{array}$ & $\begin{array}{l}-10 \\
+6\end{array}$ & $\begin{array}{l}38 \\
39 \\
43\end{array}$ & $\begin{array}{l}78 \\
47 \\
76\end{array}$ & $\begin{array}{r}40 \\
8 \\
33\end{array}$ \\
\hline 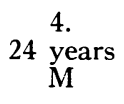 & Normal & $\begin{array}{l}301 \\
277\end{array}$ & $\begin{array}{l}+15 \\
-13\end{array}$ & $\begin{array}{l}43 \\
42 \\
45\end{array}$ & $\begin{array}{l}73 \\
69 \\
73\end{array}$ & $\begin{array}{l}30 \\
27 \\
28\end{array}$ \\
\hline $\begin{array}{l}5 . \\
26 \text { years } \\
\text { M }\end{array}$ & Ess. hypertension & $\begin{array}{l}291 \\
331\end{array}$ & $\begin{array}{l}+10 \\
+25\end{array}$ & $\begin{array}{l}26 \\
27 \\
28\end{array}$ & $\begin{array}{l}54 \\
60 \\
44\end{array}$ & $\begin{array}{l}28 \\
33 \\
16\end{array}$ \\
\hline 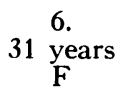 & $\begin{array}{l}\text { Pregnancy } \\
\text { mens V }\end{array}$ & $\begin{array}{l}207 \\
179\end{array}$ & $\begin{array}{l}+12 \\
-3\end{array}$ & $\begin{array}{l}32 \\
33\end{array}$ & $\begin{array}{l}43 \\
44\end{array}$ & $\begin{array}{l}11 \\
11\end{array}$ \\
\hline 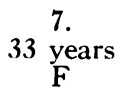 & Normal & $\begin{array}{l}255 \\
233\end{array}$ & $\begin{array}{l}+40 \\
+28\end{array}$ & $\begin{array}{l}35 \\
21 \\
24\end{array}$ & $\begin{array}{l}40 \\
66 \\
71\end{array}$ & $\begin{array}{r}5 \\
45 \\
47\end{array}$ \\
\hline \multirow[t]{2}{*}{$29 \begin{array}{l}8 . \\
\text { years }\end{array}$} & Normal & $\begin{array}{l}243 \\
240\end{array}$ & $\begin{array}{l}+13 \\
+12\end{array}$ & $\begin{array}{l}31 \\
40 \\
37\end{array}$ & $\begin{array}{l}80 \\
71 \\
53\end{array}$ & $\begin{array}{l}49 \\
31 \\
16\end{array}$ \\
\hline & & & Mean: & 35.0 & 61.5 & $\begin{array}{c}26.5=2.79 \\
\mathrm{~N}\end{array}$ \\
\hline
\end{tabular}

ference will be the same, or $26.5 \pm 3.51 \mathrm{cc}$. per liter. This value is significant. The determination of arteriovenous oxygen difference according to the direct Fick principle thus gives values about 45 per cent lower than with the acetylene method.

In order to analyze the experimental errors involved, the following procedure was adopted:

The experimental error was defined as the variability of a single determination $\left(\delta_{\mathbf{x}}\right)$ and calculated in two different ways:

The differences between determination 2 and 1 , or 3 and 2 , were computed for each method separately.

The differences 2 to 1 and 3 to 2 were of the same order of magnitude; thus all differences constituted a single group of data.

As the mean differences were not significant, the variability of a single determination may be calculated ac- cording to the following formula :

where

$$
\delta_{x}=\frac{1}{\sqrt{ } 2} \cdot \delta_{d}
$$

$$
\begin{aligned}
& \delta_{x}=\text { variability of single determination } \\
& \delta_{d}=\text { standard deviation of difference }
\end{aligned}
$$

The results are given in Table II. The greatest differences between the determinations of the catheter method were -14 and +9 , corresponding to an experimental error of 9.9 per cent (Table II). The value of -14 was found in patient No. 7 , with basal metabolic rate of +40 per cent. This value falls outside the normal range of variation. If it is excluded the experimental error (Table II) will decrease to 5.6 per cent.

The experimental error was then calculated by a combination of analysis of variance (16), using Snedecor F-ratio as test of significance (17), dif- 
TABLE II

Experimental error of the catheter and Grollman method (calculated per differences)

(a) Catheter method

\begin{tabular}{c|c|c|c|c|c}
\hline $\begin{array}{c}\text { No. } \\
\text { of } \\
\text { diff. }\end{array}$ & Mean & $\begin{array}{c}\text { Mean } \\
\text { differences } \\
D \pm \epsilon D\end{array}$ & $\begin{array}{c}\text { Stand. } \\
\text { deviation } \\
\text { of diff. }\left(\delta_{d}\right)\end{array}$ & \multicolumn{2}{|c}{$\begin{array}{c}\text { Exp. error } \\
\left(\delta_{x}\right)\end{array}$} \\
\hline 1 & 2 & 3 & 4 & 5 & 6 \\
\hline & -35.0 & $0.67 \pm 1.26$ & 4.88 & 3.46 & 9.9 \\
1.5 & 35.6 & $1.70 \pm 0.75$ & 2.81 & 1.99 & 5.6 \\
14 & 35 & $m l$. & $\begin{array}{c}\text { per cent of } \\
\text { mean }\end{array}$ \\
\hline
\end{tabular}

(b) Grollman method

\begin{tabular}{c|c|c|c|c|c}
\hline 1 & 2 & 3 & 4 & 5 & 6 \\
\hline 15 & 61.5 & $3.53 \pm 4.39$ & 17.0 & 12.1 & 21.3 \\
\hline
\end{tabular}

ferentiating between the variation between individuals $\left(\delta_{\mathbf{i}}\right)$ and within individual $\left(\delta_{\mathbf{x}}\right)$ the latter corresponding to the experimental error, and "classical analysis."

The results are given in Table III.

TABLE III

Experimental error of the catheter and the Grollman method (calculated by analysis variance)

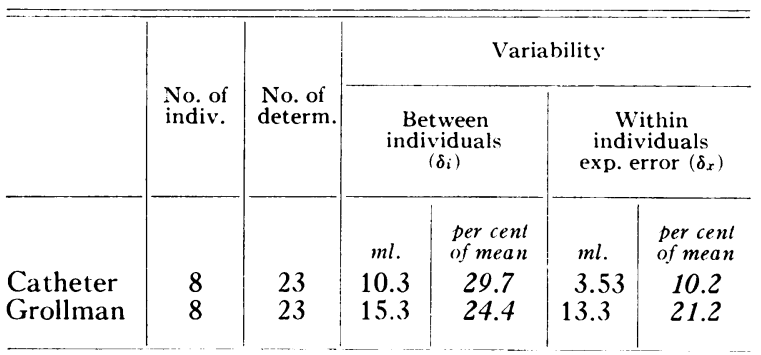

The agreement between the two methods of calculation was excellent.

The catheter method was thus found to have a coefficient of variation for a single determination of 10 per cent ( 5.6 per cent), whereas the acetylene method, applied on the same patients under the same conditions during the simultaneous catheterization had a coefficient of variation of 21 per cent, which is significantly higher. The variability between the patients was found to be about the same for both methods (30, or 24 per cent).

There was no difference in oxygen content of the blood in the pulmonary artery sampled before, or 17 to 27 seconds after, the start of rebreathing. In eight cases the maximal difference between the samples was 0.2 volumes per cent, the oxygen content being higher in some cases and lower in others during rebreathing.

The test for recirculation of acetylene showed that between five and 10 seconds after the start of acetylene breathing there was no acetylene in the pulmonary artery blood. However, in 10 to 15 seconds acetylene was present in the pulmonary artery blood, in amounts corresponding to an acetylene content in the alveolar air of 0.4 to 0.5 volumes per cent. In 15 to 20 seconds, this amount corresponded to approximately $1.5 \mathrm{vol}$ umes per cent.

\section{DISCUSSION}

In almost simultaneous determinations there was a statistically significant difference in arteriovenous difference and cardiac output of 45 per cent between values obtained with the direct Fick and the acetylene methods. This confirms earlier work in which separate determinations were done using these two methods. Bauman and Grollman have previously reported values with the acetylene method and the direct Fick that agreed fairly well (18). The mixed venous blood in their cases was sampled after puncture of the heart and the sampling done immediately after the rebreathing of acetylene, both factors making the results uncertain. The belief that the discrepancy between values for cardiac output obtained with heart catheterization and with the acetylene technique is due to apprehension produced by the catheterization is disproved by the result of this study. Instead, the difference must be due to some systematic error in the acetylene method.

Gladstone believed that the rebreathing technique augmented the circulation and thus gave rise to errors (9). The present study conclusively shows that there is no difference in oxygen content in the mixed venous blood during the short time of rebreathing as compared to that before rebreathing.

Hamilton, Spradlin and Saam, working with dogs, have shown (19) that the recirculation of acetylene is too rapid to permit waiting 25 seconds before the second air sample is taken. Rapid recirculation was confirmed by Starr and Collins, who used the dye injection technique in $\log _{s}(20)$. 
Grollman and Bauman, on the contrary, after heart puncture in man, found that significant amounts of acetylene did not appear in the blood in the right ventricle until 25 seconds after the start of acetylene breathing (18). Hohw Christensen was able to demonstrate that the acetylene content in the peripheral venous blood was very low and rose slowly, due to the diffusion of acetylene from the blood to the tissues $(21,22)$.

The present study shows that significant amounts of acetylene appear in the pulmonary artery blood between 10 and 15 seconds after the start of acetylene breathing. Since it is impossible to get full mixing and equalization of the acetylene within this time, it may be assumed that these factors are inherent sources of error in all methods using inhalation of foreign gas. This error becomes greater the longer the time elapsing before the second sample is taken. That recirculation is the main source of error is also shown by the fact that, in patients with slow circulation, e.g., cardiac failure, gas inhalation methods give values for arteriovenous oxygen difference that equal those obtained with the direct Fick principle, 90 to 100 cc. per liter of blood $(3,13,23)$. The results of dye injection experiments in man with the dye injected in the plumonary artery and the right auricle also show that there is a significant recirculation within 10 seconds (24).

\section{SUMMARY AND CONCLUSIONS}

1. Almost simultaneous determinations of cardiac output according to the direct Fick (after heart catheterization) and the acetylene methods were made in eight subjects. A total of 22 sets of determinations were made.

2. There was a statistically significant discrepancy in the values obtained by the two methods for the AV oxygen difference. The mean difference averaged $26.5 \pm 2.79 \mathrm{cc}$. per liter; the Fick method giving values about 45 per cent lower than the Grollman.

3. The experimental error for the Fick method was 5.6 per cent and for the acetylene method, 21 per cent.

4. The rebreathing procedure did not change the oxygen content in the pulmonary artery blood during the 27 seconds that the rebreathing lasted.

5 . Tests for recirculation showed that within 10 to 15 seconds after the start of acetylene breathing significant amounts of acetylene were found in the pulmonary artery blood.

6. Any method using inhalation of foreign gas will give values for arteriovenous oxygen difference which are too large, if the gas sampling is not completed before 10 to 15 seconds after the start of rebreathing. This error is not constant but, due to the speed of the circulation, is small or absent with slow circulation and is large with rapid circulation.

\section{BIBLIOGRAPHY}

1. Forssmann, W., Die Sondierung des rechten Herzens. Klin. Wchnschr., 1929, 8, 2085.

2. Cournand, A., and Ranges, H. A., Catheterization of the right auricle in man. Proc. Soc. Exper. Biol. \& Med., 1941, 46, 462.

3. Cournand, A., Riley, R. L., Breed, E. S., Baldwin, E. de F., and Richards, D. W., Jr., Measurement of the cardiac output in man using the technique of catheterization of the right auricle or ventricle. J. Clin. Invest., 1945, 24, 106.

4. Fick, A., Über die Messung des Blutquantums in den Herzventrikeln. Sitzungsber. physik. med. Ges., Würzburg, 1870, 16.

5. Lagerlöf, H., and Werkö, L., Studies on the circulation in man. II. Normal values for cardiac output and pressure in the right auricle, right ventricle and pulmonary artery. Acta physiol. Scandinav., 1948, 16, 75.

6. McMichael, J., and Sharpey-Schaefer, E. P., Cardiac output in man by a direct Fick method. Brit. Heart J., 1944, 6, 33.

7. Stead, E. A., Jr., Warren, J. V., Merrill, A. J., and Brannon, E. S., Cardiac output in male subjects as measured by the technique of right atrial catheterization. J. Clin. Invest., 1945, 24, 326.

8. Werkö, L., The influence of positive pressure breathing on the circulation in man. Acta med. Scandinav. Supp., 1947, 193.

9. Gladstone, S., Cardiac Output and Arterial Hypertension. The Author, New York, 1935.

10. Grollman, A., Determination of cardiac output of man by use of acetylene. Am. J. Physiol., 1929, 88, 432.

11. Grollman, A., The Cardiac Output of Man in Health and Disease. Thomas, Baltimore, 1932.

12. Krogh, A., and Lindhard, J., Measurements of the blood flow through the lungs of man. Scandinav. Arch. Physiol., 1912, 27, 100.

13. Berséus, S., The influence of heart glucosides, theophylline and analeptics on the cardiac output in congestive heart failure; with remarks on the acetylene methods. Acta med. Scandinav. Suppl., $1943,145$. 
14. Berséus, S., Die Wirkung von Pervitin auf den Kreislauf und die Atmung beim Menschen. Acta physiol. Scandinav., 1943, 5, 230.

15. Dahlberg, G., Statistical Methods for Medical and Biological Students. Allen \& Unwin, London, and Interscience Publ., Inc., New York, 1940.

16. Fisher, R. A., Statistical Methods for Research Workers. Oliver \& Boyd, Edinburgh, 1936.

17. Snedecor, G. W., Statistical Methods Applied to Experiments in Agriculture and Biology. Collegiate Press, Inc., Ames, Iowa, 1938.

18. Baumann, H., and Grollman, A., Über die theoretischen und praktischen Grundlagen und die klinische Zuverlässigkeit der Acetylenmethode zur Bestimmung des Minutenvolumens. Ztschr. f. klin. Med., 1930, 41, 115.

19. Hamilton, W. F., Spradlin, M. C., and Saam, H. G., $\mathrm{Jr}$., Inquiry into the basis of acetylene method of determining cardiac output. Am. J. Physiol., 1932, 100, 587.

20. Starr, I., Jr., and Collins, L. H., Jr., Estimations of the rapidity and amount of blood traversing the shorter paths of the systemic circulation. Am. J. Physiol., 1933, 104, 650.
21. Christensen, E. H., Beiträge zur Physiologie schwerer körperlicher Arbeit; der Stoffwechsel und die respiratorischen Funktionen bei schwerer körperlicher Arbeit. Ibid.; über die Brauchbarkeit der Acetylenmethode zur Bestimmung des Herzminutenvolumens während körperlicher Arbeit. Arbeitsphysiol., 1932, 5, 463, 479.

22. Christensen, H. E., Trolle, C., and Nielsen, H. E., Beiträge zur Physiologie schwerer körperlicher Arbeit; über die versuchsdauer bei minutenvolumenbestimmungen mit der während körperlicher Arbeit. Arbeitsphysiol., 1933, 7, 108.

23. Grollman, A., Friedman, B., Clark, G., and Harrison, T. R., Studies in congestive heart failure; a critical study of methods for determining the cardiac output in patients with cardiac disease. J. Clin. Invest., $1933,12,751$.

24. Lagerlöf, H., Bucht, H., Werkö, L., and Holmgren, A., Determination of the cardiac output and the blood volume in the lungs and in the right and left heart by means of colour dilution curves. Proceedings of the $21 \mathrm{st}$ Scandinavian Congress for Internal Medicine, 1948, in press. 